MINERALOGIA POLONICA

DOI 10.2478/v10002-007-0003-z

PL ISSN 0032-6267

Vol. 37, No 2, 2006

Leszek MARYNOWSKI ${ }^{1}$, Piotr WYSZOMIRSKIㄴ, Sławomir KURKIEWICZ ${ }^{3}$

\title{
THE CHARACTERISTICS OF ORGANIC MATTER FROM THE TRIASSIC CLAYS OF NW MARGIN OF THE HOLY CROSS MTS (POLAND) - PRELIMINARY REPORT
}

\author{
Received January 20, 2005; accepted July 05, 2006
}

Abstract. The molecular character of organic matter in Triassic clays on the NW border of the Holy Cross Mts was determined in apolar, aromatic and polar fractions of extractable organic matter (OM) using GC-MS analysis. The contribution of terrestrial higher plants to the kerogene is revealed by the dominant presence of odd long-chain $n$-alkanes and by the occurrence of retene. Benzophenone, fluorenone, cyclopenta(def)phenanthrenone, antracenone and benzanthrone were among the compounds identified in polar fractions of the soluble organic matter. These commonly originate during strong oxidation of sedimentary organic matter. The aromatic fraction is characterised by the presence of phenyl derivatives (PhPAC) such as phenylnaphthalenes, terphenyls, phenyldibenzofurans and phenylphenanthrenes that are also products of the abiotic oxidation of organic matter. The oxidation processes that occurred during sedimentation and during early diagenesis resulted in a very significant decrease in the organic matter content in the clays. This decrease considerably influences their technological properties.

Key-words: Triassic clays, the Holy Cross Mts, organic matter, biomarkers, maturity

\section{INTRODUCTION}

The problem of organic matter in clay raw materials used by the ceramic industry has been one of great importance over recent years. It has arisen due to the introduction of the fast firing technology, now commonly used in the production of ceramic tiles. It is assumed that the organic matter in raw material for wall and paving tiles produced in a single fast firing, expressed as elemental carbon, should be lower than $0.3 \mathrm{wt} . \%$ (de la Torre et al. 1996). Otherwise, production defects can appear resulting, among others,

\footnotetext{
1 University of Silesia, Faculty of Earth Sciences, ul. Będzińska 60, 41-200 Sosnowiec, Poland; e-mail: marynows@wnoz.us.edu.pl

2 AGH University of Science and Technology, Faculty of Material Science and Ceramics, al. Mickiewicza 30, 30-059 Kraków, Poland.

${ }_{3}^{3}$ Medical University of Silesia, Department of Instrumental Analysis, Faculty of Pharmacy, ul. Narcyzów 1, 41-200 Sosnowiec, Poland
} 
from excessive organic matter contents (Beltrán et al. 1988). The characteristics of this organic matter and its content in clay rocks are of both cognitive and industrial importance. The former aspect is a main goal of this paper.

To-date, the literature concerning Polish clay rocks and clay raw materials contains few reports on organic matter occurring in elevated amounts. Total organic matter (TOC) in the kaolin from the Kalno (Lower Silesia) deposit amounts to approx. 1.5 wt.\% (Sikora et al. 1978). Some Jurassic clays are characterised by TOC in the range 0.4-3.0 wt.\% (Zatoń, Marynowski 2004, 2006; Marynowski et al. - in preparation).

Cognitive and practical aspects are the basis for initiating the current study on the organic matter contents of clay rocks that are of considerable economic importance even if their organic matter content is distinctly lower than in the clays mentioned above. The Triassic red clays of the NW border of the Holy Cross Mts are examples of such rocks. The organic matter occurring in these clays has not, as yet, been characterized in compositional terms either quantitatively or qualitatively. One of the reasons for this is the negligible amount of organic matter in these rocks which inhibits the application of, e.g., thermal analysis. Complex analytical procedures are required to extract the organic matter from the clays as are precise chromatographic and spectroscopic analytical methods.

This paper presents data on the general character of the organic matter in the Triassic red clays (samples: Chełsty 444, Baranów 947, Kozów 873) and in grey and green lenses and intercalations (samples: Chełsty 449, Kozów 869). The molecular composition of extractable organic matter has been analysed for those organic compounds (including biomarkers) that characterize the source of this matter and the level of its thermal maturity.

\section{SAMPLES AND METHODS}

Clay samples were collected from three operating open pits at Chełsty (Keuper), Kozów (Buntsandstein) and Baranów (Buntsandstein), all on the NW border of the Holy Cross Mts (Fig. 1). Total organic carbon (TOC) was determined by the LECO method using a CR-12 apparatus.

Extraction and fractionation. Samples were Soxhlet-extracted in pre-extracted thim-bles with dichloromethane. The extracts were separated using pre-washed TLC plates coated with silica gel (Merck, $20 \times 10 \times 0.25 \mathrm{~cm}$ ). Prior to separation, the TLC plates were activated at $120^{\circ} \mathrm{C}$ for $1 \mathrm{~h}$. The plates were loaded with the $n$-hexane soluble fraction and developed with $n$-hexane/dichloromethane ( $\mathrm{V}: \mathrm{V}=97: 3)$. Bands comprising aliphatic (Rf 0.5-1.0), aromatic (Rf 0.05-0.5) and polar + asphalthenes (Rf 0.0-0.05) fractions were collected.

In addition, polar fractions were further developed with $n$-hexane/ethyl acetate $(\mathrm{V}: \mathrm{V}=9: 1)$ on TLC plates coated with silanised silica gel (Merck, $20 \times 20 \times 0.25 \mathrm{~cm}$ ). Three subfractions were obtained by this means. Polar oxygen compounds characterized the second subfraction $(\mathrm{Rf}=0.5-0.8)$. This latter, and the aliphatic and aromatic fractions were analysed in further detail.

Gas chromatography coupled with mass spectrometry (GC-MS). The analyses were performed using an Agilent 6890 Series Gas Chromatograph interfaced with an Agilent 


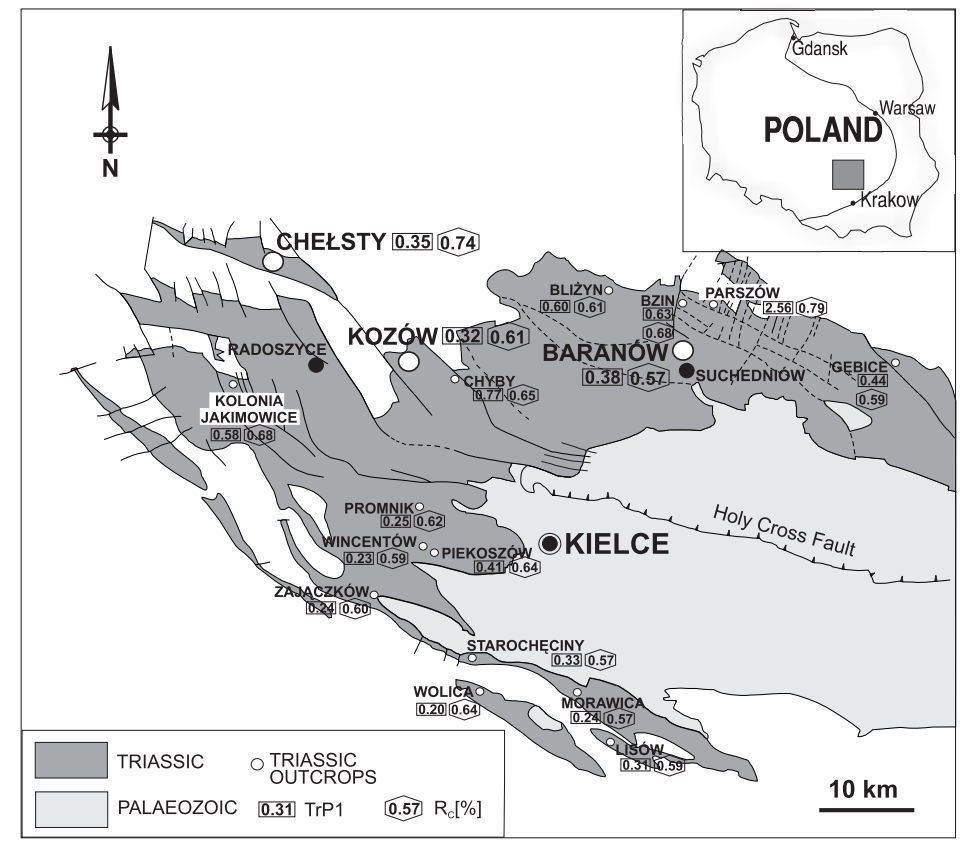

Fig. 1. Location map of the Holy Cross Mts and their northern Triassic cover. $\operatorname{TrP} 1$ - terphenyl ratio parameter (increases with increasing maturity), $R_{c}-$ calculated vitrinite reflectance value based on MPI1 (see Table 1)

5973 Network Mass Selective Detector with an Agilent 7683 Series Injector (Agilent Technologies, Palo Alto, CA). An Agilent Technologies Enhanced ChemStation G1701CA ver.C.00.00 was used for the data collection and the Wiley Registry of Mass Spectral Data 7th Edition software for the mass spectra processing. $0.5 \mu \mathrm{l}$ of sample was injected into a cool on-column injector with electronic pressure control, the temperature of which, in "Track Oven" mode, was $3^{\circ} \mathrm{C}$ higher that of the oven.

Helium 6.0 (Linde, Kraków) at a constant flow rate of $2.6 \mathrm{ml} / \mathrm{min}$. was used as the carrier gas. Analysed compounds were separated on a two fused-silica capillary columns: J\&W DB5-MS (60 $\mathrm{m} \times 0.25 \mathrm{~mm}$ i.d., $0.25 \mu \mathrm{m}$ film thickness) and DB35-MS $(60 \mathrm{~m} \times 0.25 \mathrm{~mm}$ i.d., $0.25 \mu \mathrm{m}$ film thickness).

The GC oven temperature was programmed from $40^{\circ} \mathrm{C}$ (isothermal for $1 \mathrm{~min}$ ) to $120^{\circ} \mathrm{C}$ at a rate of $20^{\circ} \mathrm{C} / \mathrm{min}$ and then to $300^{\circ} \mathrm{C}$ at a rate of $3^{\circ} \mathrm{C} / \mathrm{min}$. The final temperature was held for $35 \mathrm{~min}$. The GC column outlet was connected directly to the ion source of the mass spectrometer. The GC-MS interface was held at $280^{\circ} \mathrm{C}$ and the ion source and the quadrupole analyzer at $230^{\circ} \mathrm{C}$ and $150^{\circ} \mathrm{C}$, respectively. Mass spectra were recorded at $\mathrm{m} / \mathrm{z} 45-550$ (0-40 $\mathrm{min}$ ) and $\mathrm{m} / \mathrm{z}$ 50-700 (above $40 \mathrm{~min}$ ). The mass spectrometer operated in the electron impact mode (ionization energy: $70 \mathrm{eV}$ ).

Differential Thermal Analysis. DTA analyses were carried out using a DERIVATOGRAPH-C apparatus of Hungarian production. The analytical conditions were as follows: temperature range $25-1000^{\circ} \mathrm{C}$, heating rate $10 \mathrm{deg} \cdot \mathrm{min}^{-1}$, atmospheric air, referring substance $\mathrm{Al}_{2} \mathrm{O}_{3}$, Pt crucibles. 


\section{BULK GEOCHEMICAL DATA}

Total organic carbon (TOC) in the material studied is very low being in the range 0.05-0.14 wt.\% (Table 1). The presented data correspond to extractable organic matter contents (EOM - Table 1) which are also very low, at $c a 0.01 \%$. These observations concur with the results of thermal analysis (Fig. 2); the DTA curves do not show the diffused exothermic effect of organic matter combustion that is usually recorded between 350 and $500^{\circ} \mathrm{C}$. The DTA detection limit for organic matter amounts to $0.2 \mathrm{wt} . \%$ (Łuczak-Wilamowska, Wyrwicki 2000).

TABLE 1

Selected biomarker characteristics of organic matter in red and green clays from the Holy Cross Mts

\begin{tabular}{|c|c|c|c|c|c|c|c|c|c|c|c|c|c|}
\hline Sample & $\begin{array}{c}\text { TOC } \\
{[\%]}\end{array}$ & $\begin{array}{c}\text { EOM } \\
{[\%]}\end{array}$ & $\begin{array}{c}\mathrm{Al} \\
{[\%]}\end{array}$ & $\begin{array}{l}\mathrm{Ar} \\
{[\%]}\end{array}$ & $\begin{array}{c}\text { Pol+Asph } \\
{[\%]}\end{array}$ & $\mathrm{CPI}_{(25-31)}$ & $\mathrm{Pr} / \mathrm{Ph}$ & $\mathrm{Pr} / n \mathrm{C}_{17}$ & $\mathrm{Ph} / n \mathrm{C}_{18}$ & MPI1 & $\begin{array}{l}\text { Rc } \\
{[\%]}\end{array}$ & TrP1 & $\begin{array}{c}\text { 3-MeP/ } \\
\text { Ret }\end{array}$ \\
\hline Chełsty 444 & 0.14 & 0.012 & 34 & 7 & 59 & 0.91 & 0.95 & 0.54 & 0.57 & 0.57 & 0.74 & 0.35 & 2.68 \\
\hline Chełsty 449 & 0.07 & 0.011 & 34 & 11 & 55 & 0.99 & 0.98 & 0.84 & 0.98 & 0.16 & 0.50 & 0.39 & 1.64 \\
\hline Baranów 947 & 0.05 & 0.006 & 29 & 5 & 66 & 1.19 & 0.86 & 0.61 & 0.57 & 0.28 & 0.57 & 0.38 & 3.13 \\
\hline Kozów 869 & 0.06 & 0.008 & 71 & 12 & 17 & 1.03 & 0.56 & 0.85 & 0.73 & 0.35 & 0.61 & 0.32 & 2.61 \\
\hline Kozów 873 & 0.11 & 0.009 & 54 & 10 & 36 & 1.05 & 0.71 & 0.96 & 0.76 & 0.31 & 0.59 & 0.34 & 2.57 \\
\hline
\end{tabular}

EOM - extracatable organic matter, Al - aliphatic fraction, Ar - aromatic fraction, Pol + Asph - polar fraction and asphalthenes, $\mathbf{C P I}_{(25-31)}-$ carbon preference index for $C_{25}$ to $C_{31} n$-alkanes range, $\mathbf{P r} / \mathbf{P h}-$ pristane/phytane ratio, $\mathrm{Pr} / \mathrm{C}_{17}-$ pristane $/ n$-heptadecane ratio, $\mathbf{P h} / \mathrm{C}_{18}-$ phytane $/ n$-octadecane ratio, MPI1 - methylphenanthrene index 1, MPI1 = 1.5([2-MP] + [3-MP])/([P] + [1-MP] + [9-MP]) (Radke, Welte 1983), P - phenanthrene, MP - methylphenanthrenes, $\mathbf{R c}[\%]=0.40+0.60$ (MPI1), TrP1 - terphenyl ratio (Marynowski et al. 2001), 3-MeP/Ret - 3-methylphenanthrene/retene ratio (Wilhelms et al. 1998)

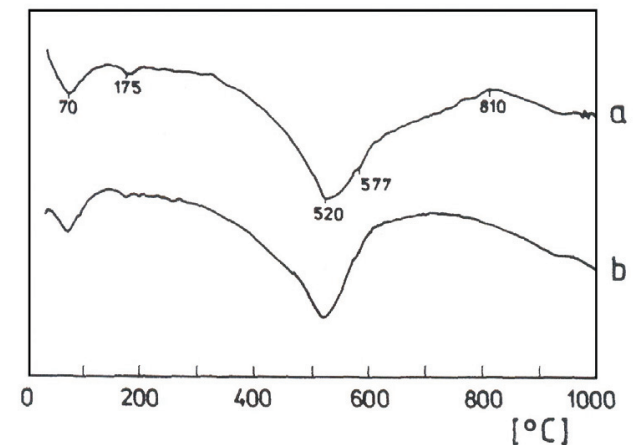

Fig. 2. DTA curves of the Triassic red clay of the Kozów deposit (sample 873) before (a) and after (b) removal of organic matter 
In the group composition of extracts obtained from all the samples, the highest are the contents of aliphatic and polar fractions while those of aromatic fraction are low and very low (Table 1). The aromatic fractions contain aromatic hydrocarbons and some aromatic oxygen- and sulphur compounds.

\section{MOLECULAR COMPOSITION OF ORGANIC MATTER}

The commonly used parameter based on the distribution of $n$-alkanes, the Carbon Preference Index $\mathrm{CPI}_{(25-31)}$, reaches values close to 1 for the samples from Chełsty and Kozów and a value above 1 for the Baranów sample (Table 1). In the latter case, the value indicates participation of higher plants in the formation of the organic matter. Relatively low $\mathrm{CPI}_{(25-31)}$ values probably reflect very intense oxidation of organic matter. Oxidation, as with increase of thermal maturity, causes cracking of long-chain $n$-alkanes and the obliteration of differences between even and odd long-chain $n$-alkanes and results in the domination of shortchains.

The contribution of organic matter of terrestrial origin to the kerogene is confirmed by the presence of retene in all of the samples studied. As is widely known, the latter is an aromatic compound originating from resinous higher plants (e.g. Otto et al. 2002). The ratio of pristane to phytane $(\mathrm{Pr} / \mathrm{Ph})$ is commonly used in the reconstruction of redox conditions during deposition of organic matter (Peters, Moldowan 1993). However, the values ranging from 0.5 to 1.0 obtained for the clays studied are not diagnostic. As reported by Volkman and Maxwell (1986) and ten Haven et al. (1987), only values of $\mathrm{Pr} / \mathrm{Ph}$ higher than 3.0 and lower than 0.5 definitively reflect oxic- and anoxic conditions, respectively.

The predominance of $n$-alkanes over isoprenoids, expressed by the indexes $\operatorname{Pr} / n C_{17}$ and $\mathrm{Ph} / n \mathrm{C}_{18}$ (Table 1 ) and by the presence of hopanes, is indicative of the participation of organic matter of bacterial origin in the kerogene. Steranes, compounds originating from eucariotic organisms, do not occur or are only present in trace amounts. Their absence can be linked to the destructive effect of oxic conditions and to bacterial reworking of organic matter during early diagenesis; steranes are less resistant to such processes than are hopanes and isoprenoids.

Organic compounds identified in sedimentary organic matter are susceptible to decomposition and advanced destruction under oxic conditions. This is particularly evident from the distribution of aromatic and low-polar hydrocarbons such as benzophenone, fluorenone, cyclopenta(def)phenanthrenone (Fig. 3), antracenone and benzanthrone (Fig. 4) in the material examined here. These hydrocarbons typically originate during strong oxidation and/or combustion of organic matter (Marynowski et al. 2004). The final stage of polycyclic aromatic hydrocarbon oxidation produces fatty acids (Anderson, Johns 1986); these, being very soluble in water, are prone to removal in migrating solutions. Polycyclic aromatic hydrocarbons such as naphthalene, biphenyl, phenanthrene, fluorene, fluoranthene, pyrene, chrysene and perylene, and especially their alkyl derivates, are present in small amounts in the analysed material (Table 1). Moreover, unsubstituted polycyclic aromatic hydrocarbons predominate over their 


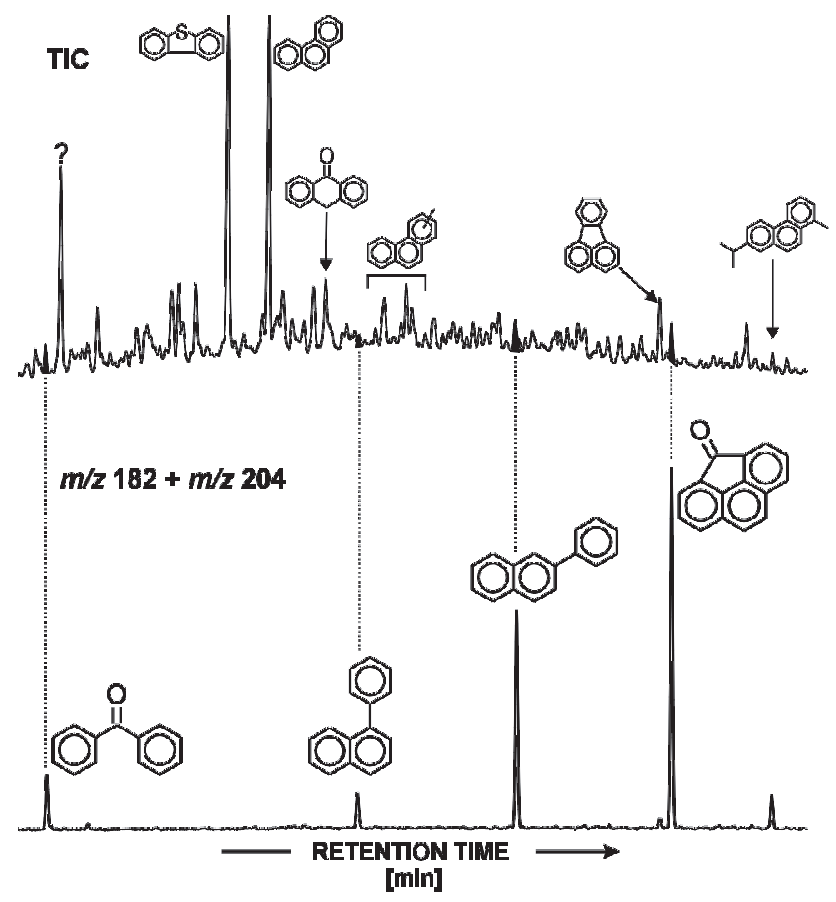

Fig. 3. Partial mass chromatogram showing distribution of benzophenone $(\mathrm{m} / \mathrm{z} 182)$ and phenylnaphthalenes + cyclopenta $(d e f)$ phenanthrenone $(\mathrm{m} / \mathrm{z} 204)$ in green clay from the Chełsty open pit (polar fraction). DB-5MS column was used

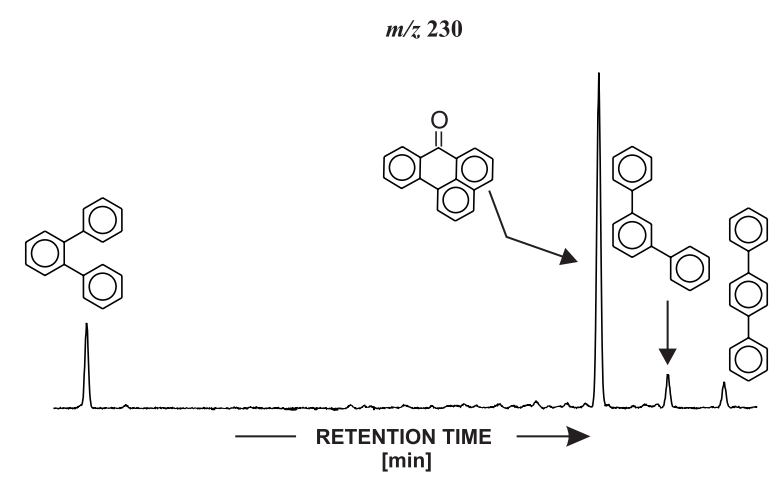

Fig. 4. Partial mass chromatogram showing distribution of terphenyls and benzanthrone $(\mathrm{m} / \mathrm{z} 230)$ in green clay from the Chełsty open pit (polar fraction). DB-5MS column was used

methyl- derivatives. This is clearly shown on Figure 5 where phenanthrene is seen to dominate over 2-, 3-, 1- and 9-methylphenanthrenes. Such a distribution of aromatic compounds, characteristic of oxidized sedimentary organic matter (e.g. Sun, Püttmann 2001), is probably a consequence of relatively fast conversion of the methyland/or ethyl groups into aromatic aldehydes and ketones (see Wilkes et al. 1998). According to Watson et al. (2005), oxygen compounds such as furans or xanthones are 

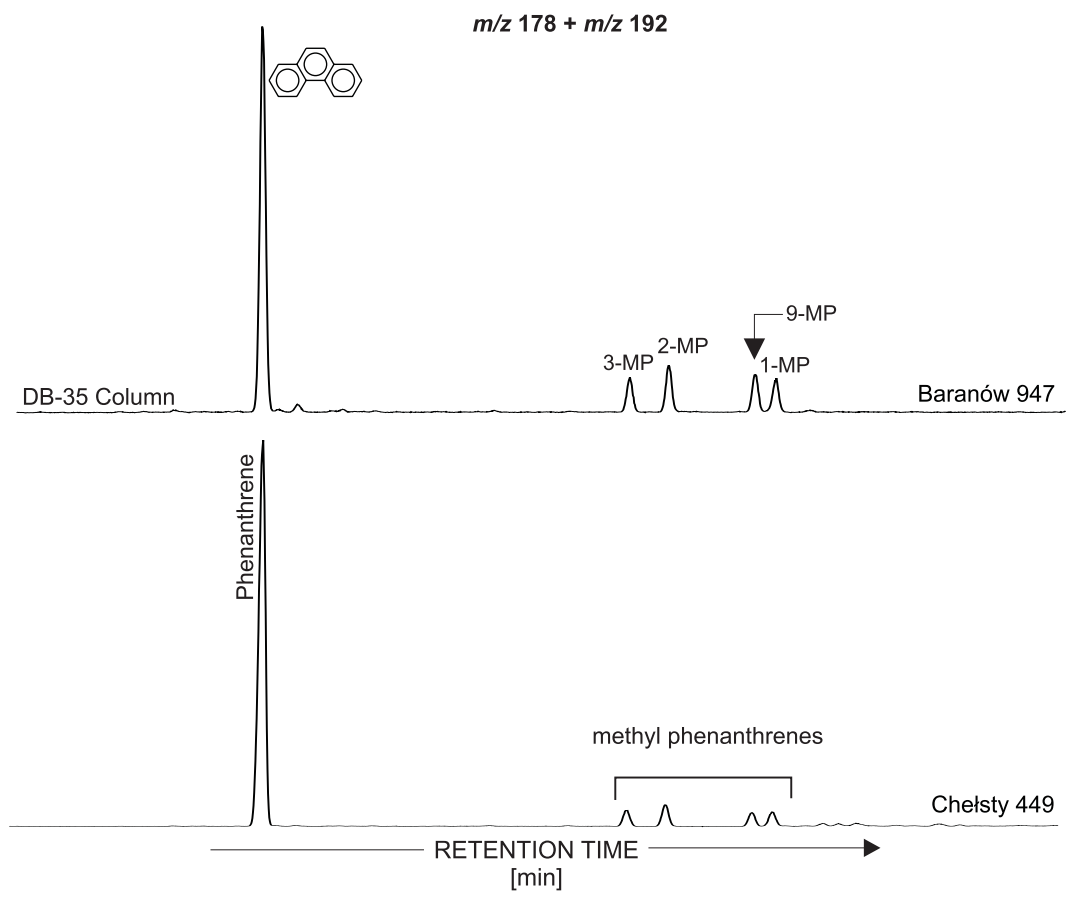

Fig. 5. Partial mass chromatograms showing distribution of phenanthrene and methyl phenanthrenes $(m / z 178+192)$ in clays from Chełsty and Baranów open pits (aromatic fraction)

genetically associated with vascular plants, fungi and lichens. However, the majority of oxygen organic compounds described in this paper are typical of diagenetic transformations caused by abiotic oxidation of organic matter (see Charrié-Duhaut et al. 2000). Moreover, the red clays contain phenyl derivates of aromatic compounds (PhPAC) such as phenylnaphthalenes (Fig. 3), terphenyls, phenyldibenzofurans and phenylphenanthrenes (Fig. 4). Their presence is not surprising as PhPAC originate during oxidation of organic matter - in many instances influenced by hydrothermal fluids (Marynowski et al. 2002a).

Other groups of organic compounds present in the clays include long-side chain alkylbenzenes, alkyltoluenes and branched long-side chain alkylbenzenes. Organic compounds of this type have been previously described in sedimentary organic matter (Fan et al. 1991; Ellis et al. 1996; Zhou et al. 2001). Their genesis, however, remains unclear (Sinninghe Damsté et al. 1988; Zhou et al. 2001).

The degree of organic matter maturity, based on the methylphenanthrene index and on the 3-methylphenanthrene/retene ratio (Table 1), is very similar in all of the clays examined and equates with that of Triassic carbonates (Marynowski et al. 2002b). Thermal maturity parameters for the clays, and for Triassic limestones and dolostones, are compared in Figure 1. 


\section{CONCLUSIONS}

The oxidation of organic matter obliterates many of the diagnostic features that identify its source. Nevertheless, the domination of odd long-chain $n$-alkanes in the Baranów material and the presence of retene in all of the samples examined are indicative of higher plant input into the kerogen. Aliphatic hydrocarbons survived oxidation to a remarkably greater extent than did aromatic hydrocarbons (see Anderson, Johns 1986). The latter were, in large measure, oxidised into ketones and chinones and, finally, into fatty acids soluble in water. Generally, these processes lowered the organic matter content in the clays to less than $0.1 \mathrm{wt}$.\%. It is important to note that a comparison of the bulk and molecular compositions of organic matter in the red clays and green lenses and intercalations reveals no significant differences.

Oxidation during sedimentation and during early diagenesis resulted in a huge decrease in the organic matter content of the Triassic clays. In ceramic raw materials, this decrease is especially advantageous in the context of fast firing technologies used in the production of ceramic tiles.

Acknowledgements. This study has been supported by KBN grant No. 1063/T08/2004/27 over the years 2004-2007 as a research project of the AGH University of Science and Technology. The authors are deeply grateful to Dr Pádhraig S. Kennan, University College Dublin, and Dr. A. Skowroński, AGH University of Science and Technology, who kindly read the manuscript and improved the English. Two anonymous reviewers are thanked for helpful comments and suggestions.

\section{REFERENCES:}

ANDERSON K.B., JOHNS R.B., 1986: Oxidation studies of Australian coals - I. Aliphatic and aromatic hydrocarbons centres of oxidative attack. Organic Geochemistry 9, 219-224.

BELTRÁN V., BLASCO A., ESCARDINO A., NEGRE F., 1988: Formation of black core during the firing of floor and wall tiles. Interceram 3.

CHARRIÉ-DUHAUT A., LEMOINE S., ADAM P., CONNAN J., ALBRECHT P., 2000: Abiotic oxidation of petroleum bitumens under natural conditions. Organic Geochemistry 31, 977-1003.

ELLIS L., LANGWORTHY T.A., WINANS R., 1996: Occurrence of phenylalkanes in some Australian crude oils and sediments. Organic Geochemistry 59, 5133-5140.

FAN P., MENG Q., YU X., 1991: Biomarkers of Upper Sinian cyanobacterial dolostones in southwest China. Journal of Southeast Asian Earth Sciences 5, 129-154.

ten HAVEN H.L., DE LEEUW J.W., RULLKÖTTER J., SINNINGHE DAMSTÉ J.S., 1987: Restricted utility of the pristane/phytane ratio as a palaeoenvironmental indicator. Nature 330, 641-643.

ŁUCZAK-WILAMOWSKA B., WYRWICKI R., 2000: Substancja organiczna w iłach poznańskich - metodyka ustalania ilości. Górnictwo Odkrywkowe 42, 2-3, 172-183 (in Polish).

MARYNOWSKI L., CZECHOWSKI F., SIMONEIT B.R.T., 2001: Phenylnaphthalenes and polyphenyls in Palaeozoic source rocks of the Holy Cross Mountains, Poland. Organic Geochemistry 32, 69-85.

MARYNOWSKI L., ROSPONDEK M., MAYER ZU RECKENDORF R., SIMONEIT B.R.T., 2002a: Phenyldibenzofurans and phenyldibenzothiophenes in marine sedimentary rocks and hydrothermal petroleum. Organic Geochemistry 33, 701-714.

MARYNOWSKI L., SALAMON M., NARKIEWICZ M., 2002b: Thermal maturity and depositional environments of organic matter in the post-Variscan succession of the Holy Cross Mountains. Geological Quarterly 46 (1), 25-36. 
MARYNOWSKI L., PIĘTA M., JANECZEK J., 2004: Composition and source of the polycyclic aromatic compounds in deposited dust from selected sites around the Upper Silesia, Poland. Geological Quarterly 48 (2), 169-180.

MARYNOWSKI L. et al. Composition, source and depositional environments of organic matter from the Middle Jurassic clays of Poland. (in preparation).

OTTO A., SIMONEIT B.R.T., WILDE V., KUNZMANN L., PÜTTMANN W., 2002: Terpenoid composition of three fossil resins from Cretaceous and Tertiary conifers. Review of Palaeobotany and Palynology 120, 203-215.

PETERS K. E., MOLDOWAN J. M., 1993: The biomarker guide. Prentice Hall, New Jersey, 363 pp.

RADKE M., WELTE D.H., 1983: The Methylphenanthrene Index (MPI). A maturity parameter based on aromatic hydrocarbons. In: M. Bjorøy et al. (eds) Advances in Organic Geochemistry 1981, 504-512. J. Wiley and Sons, New York.

SINNINGHE DAMSTÉ J.S., KOCK-VAN DALEN A.C., DE LEEUW J.W., 1988: Identification of long-chain isoprenoid alkylbenzenes in sediments and crude oils. Geochimica et Cosmochimica Acta 52, 2671-2677.

SUN Y.Z., PÜTTMANN W. 2001: Oxidation of organic matter in the transition zone of the Zechstein Kuperschiefer from the Sangerhausen Basin, Germany. Energy \& Fuels 15, 817-829.

SIKORA W.S., BUDEK L., EILMES J., 1978: Organic matter in kaolin from Kalno near Świdnica (Lower Silesia). Mineralogia Polonica 9, 2, 23-37.

de la TORRE J., LORES M.T., BASTIDA J., MONTÓN J.B., 1996: Oxidation of organic matter in powdered clays at temperatures lower than dehydroxylation temperature of clay minerals. British Ceramic Transactions 95, 5, 194-198.

VOLKMAN J.K., MAXWELL J.R. 1986: Acyclic isoprenoids as biological markers. In: Biological Markers in the Sedimentary Records (R.B. Johns, ed.) Elsevier, New York, 1-42.

WATSON J.S., SEPHTON M.A., LOOY C.V., GILMOUR I., 2005: Oxygen-containing aromatic compounds in a Late Permian sediment. Organic Geochemistry 36, 371-384.

WILHELMS A., TELNÆS N., STEEN A., AUGUSTON J., 1998: A quantitative study of aromatic hydrocarbons in a natural maturity shale sequence - the 3-methyl-phenanthrene/retene ratio, a pragmatic maturity parameter. Organic Geochemistry 29, 97-106.

WILKES H., DISCO U., HORSFIELD B., 1998: Aromatic aldehydes and ketones in the Posidonia Shale, Hils Syncline, Germany. Organic Geochemistry 29, 107-117.

ZATOŃ M., MARYNOWSKI L. 2004: Konzentrat-Lagerstätte-type carbonate concretions from the uppermost Bajocian (Middle Jurassic) of the Częstochowa area, South-Central Poland. Geological Quarterly 48, 339-350.

ZATOŃ M., MARYNOWSKI L. 2006: Ammonite fauna from uppermost Bajocian (Middle Jurassic) calcitic concretions from the Polish Jura - biogeographical and taphonomical implications. GeoBios 39, $426-442$.

ZHOU W., WU Q., WANG R., SONG Y., ZHANG L., LIU Z., 2001: Distribution of aromatic biomarkers in pyrolysates of coccolithophore. Chinese Science Bulletin 46, 246-252. 
Leszek MARYNOWSKI, Piotr WYSZOMIRSKI, Stawomir KURKIEWICZ

\title{
WSTEYPNE WYNIKI BADAŃ MATERII ORGANICZNEJ Z TRIASOWYCH IŁÓW NW OBRZEŻENIA GÓR ŚWIĘTOKRZYSKICH
}

\author{
Streszczenie
}

W pracy przeprowadzono ogólną i molekularną charakterystykę materii organicznej pochodzącej z triasowych iłów NW obrzeżenia Gór Świętokrzyskich. Badaniom poddano frakcje: apolarną aromatyczną oraz polarną wykorzystując metodę chromatografii gazowej sprzężonej ze spektrometrią mas (GC-MS). Udział lądowych roślin wyższych w składzie kerogenu został stwierdzony na podstawie obecności wśród węglowodorów nasyconych wyraźnej przewagi długołańcuchowych, nieparzystowęglowych $n$-alkanów nad $n$-alkanami parzystowęglowymi. Ponadto, wszystkie badane próbki zawierają charakterystyczny dla roślin wyższych biomarker - reten. Frakcje polarne analizowanych próbek zawierają: benzofenon, fluorenon, cyklopenta(def)fenantrenon, antracenon i benzantron. Związki te powstają podczas intensywnego, abiotycznego utleniania materii organicznej. Z kolei we frakcji aromatycznej stwierdzono występowanie fenylowych pochodnych węglowodorów aromatycznych, takich jak: fenylonaftaleny, terfenyle, fenylodibenzofurany i fenylofenantreny, również genetycznie związanych z procesami utleniania. Procesy abiotycznego utleniania materii organicznej zachodzące $w$ trakcie jej depozycji i podczas wczesnej diagenezy spowodowały znaczący spadek zawartości materii organicznej w iłach, co wpłynęło na ich właściwości technologiczne. 